discussions of Electronic Digital Computers at the 1947 National Convention of the IRE. The meeting was presided over by HARry Dinmond of the National Bureau of Standards, Washington, D. C. Speakers were as follows:

J. W. Forrester of MIT discussed "The electronic digital computer" (with mention of early attempts and existing systems), a general block diagram of a modern proposed computer, and an outline of the fundamental computer operations.

S. N. ALEXANDER of the National Bureau of Standards in his talk on "Input mechanisms for electronic digital computers" established criteria for acceptable input mechanisms. He also discussed recently developed input systems and special materials used in them.

H. H. Goldstine of the Institute for Advanced Study, Princeton, New Jersey next talked on "Electronic computing" and demonstrated how arithmetical operations as well as switching of numbers and control of computation can be realized by means of vacuumtube circuits.

"The Selectron-A tube for selective electrostatic storage" was described by J. A. Rajchman, RCA Laboratories Division, Princeton, New Jersey. See under Tzchical DEVELOPMENTS of this issue.

P. Crawford, Special Devices Division, Office of Naval Research, Washington, D. C., terminated the discussions with a talk on "Applications of electronic digital computers," which included comments on the future relation of analogue and digital computers, and also on the possible engineering application of electronic digital computers to automatic process and factory control, traffic control, and business calculations.

Because of the great interest in the computer program these talks were repeated the same day from 5 to 7 p.m.

\title{
OTHER AIDS TO COMPUTATION
}

See also our introductory article "Film Slide Rule," and QR 30.

\section{BIBLIOGRAPHY, Z-I}

1. Carlton E. Brown. "The use of double-cycle A and B scales on straight slide rules," Science, v. 101, May 18, 1945, p. 522.

2. Raymond Dudin, La Règle d̀ Calcul. Paris, Dunod, 1945, xii, 139 p. $12 \times 15.8 \mathrm{~cm}$.

3. JOSEPH T. Hogan, "Slide rules for rapid solution of special equations," The Chemist Analyst, Phillipsburg, N. J., v. 34, 1945, p. 29-39. Explanations as to how to make slide rules for special purposes.

4. ANDREW R. WEBER, "Slide rule applications to algebraic equationssolution of the cubic equation," Jn. Engin. Educ., v. 35, 1945, p. 507-514. See also Weber's "Slide rule applications to algebraic equations" [quadratic]. idem, v. 33, 1943, p. 775-780.

5. Stefan Bergman, "Punch-card machine methods applied to the solution of the torsion problem," Quart. Appl. Math., v. 4, Apr. 1947, p. 69-81. "The present paper illustrates the application of orthogonal functions to the solution of Laplace's equation $\left(\partial^{2} \phi / \partial x^{2}\right)+\left(\partial^{2} \phi / \partial y^{2}\right)=0$ through the use of punch-card machines."

6. E. G. Cox, L. Gross \& G. A. Jefrrey, "Use of punched card tabulating machines for crystallographic Fourier syntheses," Nature, v. 159, 29 Mar. 1947, p. 433-434.

7. Jack Laderman \& Milton Abramowitz, "Application of machines to differencing of tables," Amer. Statistical Assoc., Jn., v. 41, June 1946, p. 233-237. 
Last paragraph: "The foregoing Underwood-Elliott Fisher Accounting machine [Model D], a standard business machine, accomplishes more than Babbage expected of his Difference Engine and represents a marked improvement over other machines used to difference tables. The ease with which the operations of the machine can be changed, its comparative simplicity, easy manipulation, and low cost, greatly enhances [sic] its practicality and demonstrates [sic] how a machine of this type lends itself to specialized computational work. Unquestionably, many more machines of this general nature exist which appear to be unknown to scientific computers. There is no doubt that the great effort currently expended on computational work could be appreciably reduced by stimulating a wider knowledge of the capacities of existing business machines and by promoting a broader extension of their applications."

8. O. Amble, "On a principle of connexion of Bush integrators," Jn. Sci. Instruments, v. 23, 1946, p. 284-287. See Math. Rev., v. 8, 1947, p. 288.

9. G. HÄGG \& T. LAURENT, "A machine for the summation of Fourier series," Jn. Sci. Instruments, v. 23, 1946, p. 155-158. See Math. Rev., v. 8, 1947 , p. 56.

\section{NOTES}

75. Bholanath Pal's Tables of Roots of the Equations $P_{n}^{m}(x)=0$ AND $d P_{n}^{m}(x) / d x=0$ REGARDED AS EQUATIONS IN $n$. - These tables are given in Calcutta Math. Soc., Bull., v. 9, no. 2, 1919, p. 95, and v. 10, 1919, p. 188-194. The tables contain $4 \mathrm{~S}$ values of $n$, for each of 87 zeros of the equations, $\theta=15^{\circ}\left(15^{\circ}\right) 45^{\circ}, x=\cos \theta$, except for $93 \mathrm{~S}$ values. The tables give also numerous numerical details of the calculations. In Amer. Math. Soc. Bull., v. 53, Feb. 1947, p. 154-155 it was stated by C. W. HoRTon that Pal erred in listing for $P_{n}^{2}(x)=0$ the roots $n=4.77,2.26,1.52$, corresponding respectively to the values $\theta=15^{\circ}, 30^{\circ}, 45^{\circ}$. Horton also supplied 9 other early zeros which $\mathrm{Pal}$ had overlooked. These are for $P_{n}^{0}(x)=0$ and $d P_{n}^{1}(x) / d x=0, \theta=15^{\circ}\left(15^{\circ}\right) 45^{\circ}$, and for $d P_{n}^{2}(x) / d x=0, \theta=15^{\circ}, 30^{\circ}$. These 9 values are given by Horton in tables including exact reprints of Pal's 87 values of the zeros.

$\mathrm{Pal}$ points out that the roots of these equations are of very great importance in a number of physical problems involving a conical boundary. In illustration Pal gives references to papers by CARSLAW ${ }^{1}$ dealing with scattering of sound waves, and to the discussion by $\mathrm{LAMB}^{2}$ of the problem of the determination of the oscillations of a sea bounded by parallels of latitude. In his computations $\mathrm{Pal}$ used an asymptotic expansion due to $\mathrm{G}$. N. Warson (Camb. Phil. Soc., Trans., v. 22, 1918, p. 277-308).

$$
\text { R. C. A. }
$$

1 H. S. Carslaw, Math. Annalen, v. 75, 1914, p. 133f., 592; Phil. Mag., s. 6, v. 20, 1910, p. $690-691$.

2 H. LAMB, Hydrodynamics, third ed., Cambridge, 1906, \$200, p. 292; German transl., Leipzig and Berlin, 1907, p. 359f; and sixth ed., 1932, \$201, p. 306.

76. Martin Wiberg, his Tables and Difference Engine.-Brown University has recently acquired a copy of Wiberg's large volume, Tables de Logarithmes Calculées et Imprimées au moyen de la Machine a Calculer, Stockholm, Compagnie anonyme de Forsete, 1876. xii, 561 p. $17 \times 27 \mathrm{~cm}$. The text and table headings are entirely in French, and the "Avertissement," p. iii-iv, by the author is dated "Stockholm, en novembre 1875." "1875" was the date of a Swedish edition entitled Logarithmtabeller uträknade 